\title{
KEPASTIAN HUKUM PENGIKATAN AKTA PERJANJIAN JUAL BELI DI HADAPAN NOTARIS TANPA DIHADIRI PARA SAKSI
}

\author{
Agustiro Nugroho Aribowo \\ Magister Kenotariatan Universitas Jayabaya \\ E-mail: agustironugroho@yahoo.com
}

\begin{abstract}
Abstrak
Pengikatan Akta Perjanjian Jual Beli (PPJB) merupakan salah satu instrumen pengikatan yang termasuk mempunyai kekuatan pembuktian sempurna atau bersifat otentik. Pada proses perjanjian pengikatan jual beli pada praktiknya proses penandatanganan pengikatan akta perjanjian jual beli dilakukan tanpa dihadiri para saksi. Metode pendekatan yang digunakan dalam penelitian ini adalah metode pendekatan yuridis normatif dan analisis data dilakukan dengan metode analisis normatif kualitatif. Hasil penelitian menunjukan bahwa Pengikatan Akta Perjanjian Jual Beli yang tidak dihadiri para saksi memenuhi syarat formil berdasarkan Pasal 1868 KUHPerdata, pengikatan akta perjanjian jual beli tersebut akan tetap memberikan kepastian hukum kepada kontraktan karena bersifat otentik. Otensitas akta tidak berubah meskipun pada proses pengikatan akta perjanjian dilakukan tanpa dihadiri para saksi. Otensitas akta perjanjian bersifat mutlak karena dibuat oleh atau dihadapan notaris. Notaris bertanggung jawab secara penuh terhadap akta yang dibuatnya bilamana ada syarat formil dan materil yang tidak dapat dipenuhi secara lengkap. Bilamana dalam tatanan praktisnya pengikatan akta perjanjian jual beli mengakibatkan kerugian terhadap para pihak, notaris dapat dituntut secara keperdataan dan wajib mengganti kerugian yang ditimbulkan. Adapun tanggung jawab administratif yaitu dalam bentuk peringatan tertulis, pemberhentian sementara, pemberhentian dengan hormat dan pemberhentian dengan tidak terhormat.
\end{abstract}

Kata kunci: kepastian hukum; akta perjanjian; notaris; saksi.

Abstract
Binding agreement of sale and purchase (PPJB) is one of the binding
instruments which includes having a proof of strength that is perfect or
authentic. In the process of binding purchase agreement in practice the
process of signing the binding purchase agreement is carried out without
witnesses attending. The approach method used in this study is a normative
juridical approach supported by field data through observations to obtain data
relevant to the problem. Data analysis was carried out using the normative
qualitative analysis method. The results of the research show that the binding of the
sale and purchase agreement not attended by witnesses meet the formal
requirements based on Article 1868 KUHPerdata, deed the binding purchase
agreement will continue to provide legal certainty to the contractor because it is
authentic. The authenticity of the deed has not changed even though the binding
process of the agreement was done without witnesses. The authenticity of the


agreement deed is absolute because it was made by or before a notary. The notary liability of the agreement deed which is not attended by witnesses can be done when it causes losses to the parties in the first form, error; second, unlawful acts; third, there are losses. Imposition of liability to a notary may be in the form of First, the civil liability of compensation to the parties due to the loss as evidence that has perfect proofing power; secondly, administrative responsibility, namely in the form of written warnings, temporary dismissals, respectful dismissals and dishonorable dismissals.

Keywords: legal certainty; binding agreement; notary; witness.

\section{Pendahuluan}

Pada umumnya masyarakat memberikan predikat asset yang penting kepada tanah yang memiliki fungsi sosial dan kultural, sehingga seringkali terjadi konflik atau sengketa tanah baik yang bersifat vertikal ataupun horizontal. Sengketa tanah terjadi karena keterbatasan dan tingginya kebutuhan manusia kepada tanah. ${ }^{1}$ Pada prosesnya dalam pengikatan perjanjian jual beli melibatkan beberapa pihak yang salah satunya adalah pejabat notaris. Jabatan notaris terlahir dari adanya kebutuhan diantaranya masyarakat. ${ }^{2}$ Berdasarkan aspek historis notaris diangkat sebagai "pejabat umum" yang bertugas melayani masyarakat, sejalan dengan apa yang telah disampaikan oleh R. Soegondo Notodisoeryo, Notaris adalah pejabat umum openbare-ambtenaren, dalam kaitan dengan kewenangan atau tugas dan kewajiban yang utama yaitu membuat akta-akta otentik. ${ }^{3}$

Pembuatan akta otentik diharuskan oleh peraturan perundangundangan dalam rangka menciptakan kepastian hukum, ketertiban dan perlindungan hukum, sehingga makna kepastian hukum akan teraktualisasikan dengan baik jika para pihak memahami apa yang menjadi tujuan dalam akta dapat dipahami dengan baik. ${ }^{4}$

Ada tiga unsur utama bagi terwujudnya akta otentik, pertama bentuk akta otentik harus ditentukan oleh undang-undang, kedua dibuat oleh atau dihadapan pejabat umum, ketiga akta tersebut dibuat oleh atau dihadapan pejabat umum dalam wilayah jabatan kewenangannya. Dengan demikian, hakikatnya seorang notaris di dalam menjalankan fungsi dan tugasnya harus

1. Bernhard Limbong, Opini Kebijakan Agraria, PT. Dharma Karsa utama, Jakarta, 2014, hlm. i.

2. Pengurus Pusat Ikatan Notaris Indonesia, Jati Diri Notaris Indonesia, PT. Gramedia Pustaka, Jakarta, 2009, hlm. 50.

3. R. Soegondo Notodisoeryo, Hukum Notaris Di Indonesia Suatu Penjelasan, PT. Raja Grafindo Persada, Jakarta, 1993, hlm. 42.

4. Felix The, Perlindungan Hukum Atas Kriminalisasi Terhadap Notaris, Fakultas Hukum, Universitas Diponegoro, Jurnal Masalah-Masalah Hukum, Jilid 46, 3 Juli 2017, hlm. 219. 
berprinsip kehati-hatian karena pertanggungjawabannya tidak hanya sebatas sampai pensiun dari jabatannya. ${ }^{5}$

Pada prosesnya notaris membuat pengikatan antara penjual dan pembeli dengan suatu pengikatan perjanjian, hal tersebut dilakukan untuk melindungi para pihak dari ketidakpastian hukum dan mencegah terjadinya akibat hukum yang tidak dikehendaki. Perjanjian yang dimaksud adalah perjanjian yang dilakukan antara pihak yang satu dalam hal ini penjual atau dengan pihak yang lainnya dalam hal ini penerima atau pembeli. Perjanjian secara umum merupakan hubungan hukum antara satu pihak atau lebih dengan pihak lainnya atau lebih yang saling mengikatkan dirinya. Pengertian perjanjian dijelaskan dalam Pasal 1313 Kitab Undang-Undang Hukum Perdata (selanjutnya disebut dengan KUH Perdata). Asas kebebasan berkontrak dimaknai pemberian kebebasan untuk melakukan perjanjian atau tidak melakukan perjanjian. ${ }^{6}$ Peranan notaris dalam pembuatan akta perjanjian kredit perbankan sangatlah penting di mana notaris, sebagai pejabat umum dituntut untuk bersikap profesional yang salah satunya adalah menjebatani kepentingan kreditur dan debitur dalam pembuatan akta perjanjian kredit. ${ }^{7}$

Pada praktiknya penulis mengambil contoh di tempat penulis bekerja yaitu di Bank Permata, yakni proses sampai pada tahapan timbulnya proses pengikatan perjanjian di bank pada umumnya dilakukan dengan berbagai tahapan, pertama calon debitur bertemu dengan pihak marketing bank untuk mengajukan permohonan dengan melengkapi persyaratan administrasi, kemudian pihak marketing akan menyampaikan kelengkapan dokumen terkait kepada pihak analis, dan pihak analis ini menganalisa kemampuan nasabah apakah masuk kategori yang layak diberikan pembiayaan oleh bank atau tidak dan juga dengan beberapa instrumen yang telah ditentukan oleh bank. Jika ini disetujui permohonannya oleh bank, maka melalui pihak marketing akan menyampaikan Surat Persetujuan Permohonan (SPPK) dan atau LOO (Letter Of Offering) kepada calon debitur, jika isi dari SPPK/LOO itu telah disepakati oleh calon debitur langkah selanjutnya adalah pihak legal bank akan membuatkan order ke notaris rekanan berdasarkan SPPK tersebut dan mengajukan order tersebut ke notaris rekanan bank yang telah dipilih.

Adapun persyaratan dokumen yang harus dipenuhi oleh calon debitur pada umumnya yaitu asli Sertifikat, IMB, dan PBB tahun terakhir dan dokumen identitas lainnya yang wajib dipenuhi sebagai suatu jaminan di bank,

5. Ibid., hlm. 221.

6.Agus Yudha Hernoko, Hukum Perjanjian Asas Proposional Dalam Kontrak Komersial, Kencana, Jakarta, 2014, hlm. 110.

${ }^{7}$ Mariah kamelia at.all, Peran Notaris Dalam Pembuatan Akta Perjanjian Kredit Dalam Perspektif Hukum Positif dan Hukum Islam, Program Magister Kenotariatan, Universitas Sultan Agung, Jurnal Fakta, Volume 4 Nomor 4, Desember, 2017, hlm. 577. 
selanjutnya notaris akan melakukan pengecekan asli sertifikat ke kantor pertanahan untuk memastikan telah memenuhi syarat untuk dilakukan proses pembebanan hak tanggungan pada sertifikat tersebut, dan jika telah memenuhi syarat-syarat yang telah ditentukan, maka notaris akan menentukan jadual pengikatan perjanjian nya. Pada proses hubungan kontraktual antara bank dengan debitur seringkali dilakukan proses pengikatan akta perjanjian jual beli sebagai bagian kebutuhan proses kredit ataupun pada kondisi sebagai syarat dalam pengikatan perjanjian kredit bank. Efty Hendaru Sudibyo dan Amin Purnawan ${ }^{8}$ menjelaskan Apabila piutang itu hapus karena pelunasan atau sebab-sebab lain, dengan sendirinya Hak Tanggungan itu hapus juga. Hak Tanggungan merupakan jaminan utang yang pembebanannya adalah untuk kepentingan kreditor.

Dalam proses pengikatan akta perjanjian jual beli, notaris sesuai dengan kewenangannya mempunyai andil dalam pengikatan akta perjanjian yang dilakukan antara nasabah dengan bank. Secara prosedural pengikatan akta perjanjian dimohonkan oleh bank baik itu melalui notaris rekanan. Proses pengikatan jual beli dimohonkan terlebih dahulu kepada notaris melalui surat order notaris yang substansinya memohon untuk melakukan pengikatan pengikatan akta perjanjian jual beli yang sesuai dengan order notaris. Setelah memenuhi syarat yang telah ditentukan bank nasabah dan notaris melakukan kesepakatan penandatanganan dengan waktu yang telah disepakati bersama. Pada proses pengikatan akta perjanjian jual beli pada praktiknya proses penandatanganan pengikatan akta perjanjian jual beli dilakukan tanpa dihadiri para saksi, proses yang seharusnya adalah pembacaan akta dilakukan oleh notaris dihadapan para pihak yang dihadiri para saksi.

"Pengikatan Akta Perjanjian Jual Beli bersifat bebas yang substansinya berisikan janji-janji para kontraktan. Mengalihkan hak kepada pihak lain sehingga peralihan tersebut mendapatkan kepastian, ketertiban dan perlindungan hukum urgensinya sebagai alat bukti tertulis yang bersifat otentik mengenai keadaan, peristiwa atau perbuatan hukum yang dilaksanakan melalui jabatan tertentu, dengan demikian dibutuhkan seorang pejabat yang berwenang untuk melakukan hal tersebut". 9

${ }^{8}$ Efty Hendaru Sudibyo at.all, Peranan Notaris Dalam Pembuatan Akta Izin Roya Hak Tanggungan Karena Hapusnya Hutang Dalam Perspektif Kepastian Hukum, Magister Kenotariatan, Universitas Islam Sultan Agung, Jurnal Akta, Volume 4 Nomor 2 Juni 2017, hlm. 186.

9 Habib Adjie, Hukum Notaris Indonesia-Tafsir Tematik Terhadap Undang-Undang Nomor 30 Tahun 2004 tentang Jabatan Notaris, Rafika Aditama, Bandung, 2008. hlm. 14. 
Pengikatan akta perjanjian jual beli (Tanah dan Bangunan) dalam praktiknya dibuat dalam bentuk akta otentik sebagai langkah awal menjaga komitmen untuk melakukan peralihan hak dalam bentuk Akta Jual Beli, meskipun pada hakikatnya bentuk akta perjanjian jual beli tersebut tidak ada dalam KUHPerdata, namun perkembangan kebutuhan masyarakat mengharuskan perjanjian tersebut lahir dengan asas kebebasan berkontrak. Pengikatan akta perjanjian jual beli dibuat secara otentik yang bertujuan untuk memberikan kepastian dan perlindungan hukum bagi para pihak. Melalui notaris para pihak dapat merumuskan isi klausula sesuai kepentingan dalam Pengikatan akta perjanjian jual beli. Akan tetapi, pada prosesnya pengikatan akta perjanjian jual beli tidak selalu berjalan dengan baik adakalanya perjanjian tersebut mengalami pembatalan baik dilakukan oleh para pihak ataupun melalui putusan pengadilan sehingga mempunyai dampak secara yuridis. Pengikatan akta perjanjian jual beli (PPJB) yang dilakukan notaris dilakukan tanpa kehadiran para saksi merupakan praktik yang tidak sesuai dengan ketentuan Undang-Undang Nomor 2 Tahun 2014 tentang Perubahan Atas Undang-Undang Nomor 30 Tahun 2004 tentang Jabatan Notaris yaitu minimal 2 (dua) orang saksi.

Dengan demikian notaris pada saat melaksanakan pengikatan perjanjian mengesampingkan Pasal 40 ayat 1 yang mensyaratkan hadirnya para saksi dihadapan notaris sedangkan penekanan mengenai akta otentik berdasarkan Pasal 1868 KUHPerdata.

Dari praktik di atas dapat kita telaah lebih dalam bahwa idealnya hasil dari pembuatan pengikatan akta perjanjian jual beli notaris akan berbentuk akta otentik sesuai dengan Pasal 1868 KUHPerdata, akan tetapi jika aktualisasinya tanpa kehadiran para saksi maka apakah akta notaris tersebut akan tetap memberikan kepastian hukum bagi para pihak. Pada praktiknya (dass sein) dalam Pengikatan akta perjanjian jual beli dihadapan notaris seringkali ada hal yang tidak sesuai pada proses penandatanganan perjanjian dilakukan, hal tersebut apakah merupakan unsur kesengajaan atau memang karena ketidaktahuan seorang notaris.

Dalam hal terpenuhinya syarat formil unsur essensial akta otentik yaitu Pertama, harus dalam bentuk yang ditentukan oleh undang-undang, Kedua, dibuat oleh dan di hadapan pejabat umum, ketiga, akta yang dibuat oleh atau dihadapan pejabat umum yang berwenang untuk itu dan ditempat di mana akta itu dibuat. Jika tidak terpenuhi syarat formal tersebut maka akta tersebut tidak sempurna.

Dalam ketentuan syarat formil yang ditentukan undang-undang artinya spesifikasi bentuk akta tersebut mengacu pada ketentuan peraturan perundang-undangan. Dibuat dihadapan pejabat umum artinya akta otentik 
dibuat di hadapan pejabat umum yang berwenang yang ditunjuk oleh undang undang diantaranya adalah notaris jika terkait dengan akta pengikatan akta perjanjian jual beli. Sedangkan terkait di hadapan pejabat umum yang berwenang di mana akta itu dibuat berkaitan dengan yurisdiksi kewenangan pejabat pembuat akta otentik berdasarkan wilayah di mana akta tersebut dibuat.

Syarat materil akta otentik adalah pertama, berisi kesepakatan para pihak, kedua, isi keterangan perbuatan hukum dan ketiga, pembuatan akta sengaja dimaksudkan sebagai bukti. Dalam syarat materil tersebut dapat diinterpretasikan yang substansinya akta tersebut dibuat berdasarkan kesepakatan para pihak, dalam akta menjelaskan isi kepentingan dalam bentuk perbuatan hukum dan akta tersebut dimaksudkan sebagai alat bukti.

"Mengenai bentuk perjanjian tidak ada ketentuan yang mengikat, karena perjanjian dapat dibuat secara lisan maupun tertulis. Dalam hal dibuat secara tertulis, perjanjian mempunyai makna sebagai alat bukti bila pihak-pihak dalam perjanjian itu mengalami perselisihan. Untuk perjanjian tertentu, undang-undang menentukan bentuk tersendiri sehingga bila bentuk itu diingkari maka perjanjian tersebut tidaklah sah. Dengan demikian bentuk tertulis suatu perjanjian tidak saja sebagai alat pembuktian, tetapi juga untuk memenuhi syarat adanya peristiwa (perjanjian) itu." 10

Kajian ini menarik karena dua hal, pertama, Bagaimana kepastian hukum dalam hubungannya akta otentik dengan tidak hadirnya para saksi apakah merupakan suatu hal yang esensial untuk mencapai tatanan praktis akta otentik dalam upaya pemenuhan aspek formil dan materil, kedua, tanggung jawab seperti apa yang dapat dibebankan kepada notaris di dalam mempertanggungjawabkan akta pengikatan akta perjanjian jual beli yang dilakukan tanpa kehadiran para saksi.

\section{Permasalahan}

Berdasarkan latar belakang yang telah penulis paparkan, penulis mengidentifikasi beberapa permasalahan sebagai berikut Pertama, Bagaimana kepastian hukum pengikatan akta perjanjian jual beli dihadapan notaris tanpa dihadiri para saksi ? Kedua, Bagaimana tanggung jawab notaris terhadap pengikatan akta perjanjian jual beli dihadapan notaris tanpa dihadiri para saksi ?

10. I Ketut Oka Setiawan, “Hukum Perikatan”, Sinar Grafika, Jakarta, 2016, hlm. 43. 


\section{Metode Penelitian}

Penelitian ini menggunakan penelitian yuridis normatif. Para praktisi/akademisi/pakar hukum yang berhubungan langsung dalam pembuatan pengikatan akta perjanjian jual beli, para pakar hukum yang relevan dengan pengikatan akta perjanjian jual beli yang telah dituangkan dalam bentuk buku, jurnal dan tulisan karya ilmiah lainnya yang mana kita sebut dengan penelitian yuridis normatif. Analisis data baik yang bersifat primer dan sekunder dilakukan dengan normatif kualitatif.

\section{Pembahasan}

\section{Kepastian Hukum Pengikatan Akta Perjanjian Jual Beli Di Hadapan Notaris Tanpa Dihadiri Para Saksi}

Bank di dalam menjalankan fungsinya memberikan kepada nasabah diikat dengan hubungan kontraktual dalam bentuk akta perjanjian, diantara akta yang dibuat notaris secara notaril adalah akta perjanjian jual beli yang bertujuan untuk memberikan kepastian dan perlindungan kepada kontraktan. Notaris sebagai pejabat umum mempunyai kewenangan untuk membuat akta otentik, akta otentik tersebut mempunyai kekuatan pembuktian yang sempurna sehingga dapat menjamin kepastian hukum jika terjadi wanprestasi antara para pihak. Pemberian pembiayaan oleh bank sebagai suatu lembaga keuangan harus dapat memberikan perlindungan hukum bagi para pemberi dan penerima, bagi para pihak kepastian hukum yang kuat akan memberikan keamanan dan kenyamanan di dalam melakukan perjanjian. ${ }^{11}$

Notaris merupakan pekerjaan yang menuntut dirinya mengedepankan profesionalisme, keluhuran martabat profesi dan mengedepankan kepastian dan pertanggungjawaban hukum di dalam menjalankan tugas dan fungsinya sebagai pejabat umum. Notaris dituntut untuk memiliki kemahiran teknis yang mumpuni untuk menjamin akta yang dibuatnya mempunyai mutu tinggi yang bernilai pembuktian yang sempurna, kepastian dan tanggung jawab hukum. Menurut pendapat penulis dua hal notaris mempunyai kualifikasi mutu tinggi. Pertama, notaris menjalankan tugas dan fungsinya sesuai dengan UndangUndang Jabatan Notaris, kedua notaris menjunjung tinggi dan menjalankan etika profesinya.

Pencapaian kepastian hukum itu terbagi dua unsur utama, pertama, hukumnya itu sendiri yang harus tegas dan tidak multi interpretatif, kedua, kekuasaan itu sendiri yang melaksanakan hukum tidak boleh semena-mena di

11. Anton Suyatno, Kepastian Hukum Dalam Penyelesaian Macet Melalui Eksekusi Jaminan Hak Tanggungan Tanpa Proses Gugatan Pengadilan, Kencana, 2016, Jakarta, hlm. 225. 
dalam menerapkan hukum dan berpegang teguh kepada asas legalitas. ${ }^{12}$ Kepastian hukum dalam sebuah akta perjanjian merupakan nilai yang substansial, kepastian hukum tersebut memberikan perlindungan bagi para pihak dan nilai-nilai tanggung jawab notaris sebagai pembuat akta terlaksana dengan baik. Tidak terpenuhinya kepastian hukum akan memberikan lahirnya ketidaknyamanan dan ketidakamanan. Masyarakat yang mempunyai kepentingan dalam pelayanan akan mempunyai pandangan yang tidak baik kepada notaris sebagai pejabat umum.

Jabatan notaris pada hakikatnya mempunyai dua tugas inti yang fundamental, pertama, memberikan pelayanan dan memberikan kepastian hukum terhadap akta-akta yang dibuatnya, kedua, notaris diberikan kewenangan untuk menjaga konsistensi penguatan hukum pada wilayah hukum keperdataan untuk menjamin rasa aman dan ketentraman kepada masyarakat. Hal tersebut jika di telaah berdasarkan teori kepastian hukum Gustav Radbruch yang menyatakan keadilan dan kepastian hukum jika diperhatikan dengan baik akan menjamin keamanan dan ketertiban suatu negara. Hukum positif dijunjung dan ditaati untuk mencapai tujuan hukum itu sendiri yaitu kepastian hukum dan keadilan.

Substansi notaris yang telah dikemukakan dalam Pasal 1 angka 1 Undang-Undang Nomor 2 Tahun 2014 Atas Perubahan Undang-Undang Nomor 30 Tahun 2004 tentang Jabatan Notaris, pada intinya notaris adalah pejabat umum yang diberikan wewenang untuk membuat akta otentik. Pemberian kewenangan ini ada sebagai bagian dari terciptanya kepastian hukum kepada masyarakat pada wilayah keperdataan seperti hubungan kontraktual, perjanjian, jual beli, kewarisan dan bentuk akta lainnya sepanjang kewenangan tersebut diberikan kepada notaris.

Teori kepastian hukum yang telah dikemukakan oleh Gustav Radbruch yang menyatakan keadilan dan kepastian hukum jika diperhatikan dengan baik akan menjamin keamanan dan ketertiban akan dapat dicapai dengan baik jika seorang pejabat umum menjunjung tinggi norma-norma dan peraturan perundang-undangan khususnya pasal 1868 KUHPerdata mengenai akta otentik, sehingga dapat menjamin terciptanya kepastian hukum kepada masyarakat. Dalam teori kepastian hukum, Hans Kelsen juga menegaskan bahwa undang-undang yang berisi aturan yang bersifat umum menjadi pedoman bagi individu yang bertingkah laku dalam masyarakat, baik dalam hubungannya dengan sesama individu maupun dalam hubungannya dengan masyarakat. Adanya aturan tersebut dan pelaksanaannya menimbulkan suatu kepastian hukum.

12. E. Fernando M. Manulang, Legisme Legalitas Dan Kepastian Hukum, Frenada Media Group, Jakarta, 2016, hlm. 154. 
Akta otentik maupun akta bawah tangan pada prinsipnya bertujuan sebagai alat bukti, akta otentik secara teoritis akan memberikan kekuatan pembuktian yang sempurna sehingga dengan kesempurnaanya akta tersebut dilihat apa adanya dan tidak dapat ditafsirkan lain, sedangkan akta bawah tangan mempunyai kekuatan pembuktian sepanjang para pihak mengakuinya dan tidak ada penyangkalan dari salah satu pihak baik dari aspek substansi akta dan teknis penandatangan akta, sehingga akta tersebut dapat ditafsirkan lain oleh hakim jika ada penyangkalan dalam gugatan. Akta otentik maupun akta bawah tangan secara substansial harus menenuhi ketentuan rumusan syarat sahnya suatu perjanjian yaitu berdasarkan Pasal 1320 KUH Perdata, dan pada aspek materil merupakan undang-undang bagi mereka yang melaksanakan perjanjian tersebut (Pasal 1338 KUHPerdata) (Pacta sunt servanda). Nilai kekuatan pembuktian sempurna pada akta otentik pada perjanjian tidak dengan sendirinya, akan tetapi harus melalui proses yang sesuai dengan peraturan perundang-undangan.

Penulis pada penelitian ini memfokuskan pembahasan Pasal 1868 KUHPerdata yang menyatakan :

Pasal 1868 KUHPerdata berbunyi "Suatu akta otentik ialah suatu akta yang dibuat dalam bentuk yang ditentukan Undang-undang oleh atau dihadapan pegawai umum yang berkuasa untuk itu di tempat di mana akta itu dibuat"

Sedangkan syarat materil akta otentik yaitu berisi kesepakatan para pihak, isi keterangan perbuatan hukum dan pembuatan akta sengaja dimaksudkan sebagai bukti. Kedua syarat baik formil dan materil harus diaktualisasikan oleh notaris dengan baik, karena pada prinsipnya notaris mempunyai tanggungjawab untuk melaksanakan persyaratan formil dan materil tersebut. Di dalam membuat akta perjanjian jual beli notaris harus berupaya untuk melengkapi dengan mempunyai nilai kebenaran, kejelasan dan keabsahan misalnya mulai dari kepala akta harus mencerminkan isi akta secara substansial, tidak dibenarkan mengandung typo pengetikan atau bentuk lain kekeliruan pada kepala akta. Redaksi dalam setiap pasal yang dituangkan harus lugas dan jelas tidak mengandung arti yang bersifat multi interpretatif sehingga dapat ditafsirkan berbeda, Setiap pasal harus memberikan deskripsi utuh dan mengandung kepastian hukum dan tidak berpindah ke pasal lain secara tidak jelas, memuat secara detail dan teknis jika ada sesuatu hal yang harus diatur dalam perjanjian.

Di samping itu pada proses pembuatan akta perjanjian jual beli juga harus mengandung kebenaran dengan memberikan nasihat hukum terlebih dahulu kepada penghadap mengenai pentingnya kebenaran pembuatan akta dan akibat hukum jika tidak menyampaikan segala sesuatu dengan tidak 
sebenarnya. Notaris harus berupaya untuk memitigasi risiko kemungkinan terjadinya sengketa dengan penyusunan akta perjanjian legal aman dan kuat sehingga melahirkan kepastian hukum bagi penghadapnya. Dalam upaya mencapai kepastian hukum notaris perlu memperhatikan aspek syarat formil dan materil dengan menggunakan prinsip-prinsip kehati-hatian dan meminimalisir kesalahan dikemudian hari. Pengetahuan yang luas di dalam praktik pembuatan akta perjanjian sangat diharapkan akan memberikan pengaruh terhadap kualitas akta yang dibuat.

Notaris di dalam menjalankan tugas dan fungsinya membuat serta menilai suatu akta berdasarkan asas praduga sah (presumptio iustae causa) maknanya apapun akta yang dibuat oleh notaris harus dianggap berlaku secara sah sampai ada pihak yang mempunyai kewenangan menyatakan akta tersebut tidak sah. Sehingga penggunaan asas tersebut sangat relevan secara substansial dengan Pasal 1868 KUHPerdata yang pada prinsipnya otensitas akta akan tetap melekat terhadap akta yang dibuat oleh notaris, selagi tidak ada pihak yang mempunyai kewenangan dalam hal ini pengadilan menyatakan akta tersebut merupakan akta yang mempunyai kekuatan pembuktian di bawah tangan atau akta tersebut dibatalkan.

Dalam tatanan praktisnya pada pembuatan akta perjanjian jual beli yang dibuat di hadapan notaris namun tanpa dihadiri para saksi mengacu kepada Pasal 1868 KUHPerdata dan asas praduga sah (presumptio iustae causa) maka harus dianggap sah dan mengikat serta bersifat otentik, sampai ada pihak yang berwenang yang menyatakan secara yuridis akta tersebut tidak otentik atau dibatalkan. Dengan demikian, praktik pembuatan akta perjanjian jual beli yang tidak dihadiri para saksi akan tetap bernilai otentik, otensitas akta melekat kepada akta tersebut.

Argumentasi otensitas akta perjanjian jual beli tetap melekat dalam upaya pencapaian nilai-nilai kepastian hukum yang ada pada akta otentik tersebut, jika hal teknis dalam hal mengesampingkan kehadiran saksi sebagai ukuran yang dapat menggugurkan akta perjanjian jual beli sangat riskan terjadinya kerugian bagi para pihak bahkan notaris. Norma yang ada Pasal 1868 KUHPerdata tidak mengatur secara teknis namun mengatur secara substansial terminologis makna akta otentik. Dengan mendasari pada norma terminologis yang ada pada Pasal $1868 \mathrm{KUHPerdata}$ tersebut penulis meyakini akta perjanjian jual beli meskipun tidak dihadiri para saksi akan tetap menjadi akta otentik.

Nilai moral dalam pembuatan akta otentik lebih penting seperti kejujuran, kesadaran terhadap batas-batas kewenangan pada proses pembuatan akta perjanjian jual beli lebih dikedepankan untuk menilai otensitas suatu akta. Pada prinsipnya ketidakhadiran para saksi dalam proses 
pembuatan akta otentik hanya akan memberikan ketidaksempurnaan teknis dalam proses pembuatan akta, jika para pihak sepakat dengan ketidakhadiran para saksi karena sesuatu hal keadaan memaksa dan dikemudian hari tidak ada penyangkalan oleh para pihak terhadap akta yang dibuat oleh notaris, maka pada hakikatnya otensitas akta perjanjian jual beli tidak hilang dengan ketidakhadiran para saksi.

Profesi notaris dituntut berdasarkan kualitas akta yang dihasilkan bukan substansi materi akta yang dibuat, materi akta pertanggungjawabannya dibebankan kepada para pihak yang melakukan perjanjian, namun notaris secara etik harus memberikan nasihat ketika materi akta dinilai bertentangan dengan ketentuan peraturan perundang-undangan. Akta perjanjian jual beli merupakan perjanjian yang lumrah dilaksanakan, jika pada prosesnya belum memenuhi ketentuan tentunya masalah yang paling mendasar dari hal tersebut adalah etika dan moral yang tidak dapat diatur melalui undangundang karena berkaitan dengan pribadi notaris. Kepastian hukum dalam akta otentik pada prinsipnya tidak dapat diukur secara matematis namun implikasinya mempunyai dampak kepastian hukum.

Dalam upaya memberikan kepastian hukum notaris harus memastikan dalam menjalankan jabatannya menggunakan prinsip kehati-hatian. Keterangan para pihak yang menghadap untuk dibuatkan akta perjanjian jual beli haruslah digali kebenaran formil dan materilnya. Jika notaris sudah menjalankan prinsip kehati-hatian terhadap akta perjanjian jual beli yang dibuatnya maka akta tersebut telah memiliki otensitas akta meskipun tanpa dihadiri para saksi. Jika melihat pada akta perjanjian yang otensitasnya tidak diragukan dalam tatanan praktisnya banyak yang dibatalkan atau dinilai mempunyai kekuatan pembuktian di bawah tangan bukan karena proses tidak hadirnya para saksi namun lebih kepada wanprestasi yang dilakukan dari materi akta tersebut yang salah satunya terkait dengan hak dan kewajiban.

Pada dasarnya kehadiran saksi sangat penting untuk memastikan adanya akta perjanjian jual beli tersebut dilakukan, namun bukan ukuran hilangnya otensitas akta yang telah dibuat oleh notaris serta nilai kepastian hukumnya menjadi berkurang. Argumentasi terminologis dalam Pasal 1868 KUHPerdata menjelaskan jika suatu akta telah dibuat dalam bentuk yang telah ditentukan undang-undang oleh atau di hadapan pejabat umum yang diberikan kewenangan, maka pada prinsipnya otensitas akta akan tetap melekat dan memberikan kepastian hukum meskipun dalam akta perjanjian jual beli tersebut tidak dihadiri para saksi. 
Tanggung Jawab Notaris Terhadap Pengikatan Akta Perjanjian Jual Beli Di Hadapan Notaris Tanpa Dihadiri Para Saksi

Notaris di dalam menjalankan tugas dan fungsinya harus menjunjung tinggi norma-norma yang ada di dalam peraturan perundang-undangan khususnya Undang-Undang Nomor 2 Tahun 2014 atas perubahan UndangUndang Nomor 30 Tahun 2004 tentang Jabatan Notaris dan Kode Etik Notaris. Pelanggaran terhadap ketentuan UUJN berakibat pada akta hanya mempunyai kekuatan pembuktian sebagai akta dibawah tangan dan akan menyebabkan akibat hukum serta dampak kerugian bagi para pihak baik itu penjual maupun pembeli sampai pada dimungkinkannya kebatalan akta oleh pengadilan. Dalam hal menimbulkan kerugian maka seorang pejabat umum dapat dimintakan pertanggungjawaban atas kelalaian yang dilakukan dalam pembuatan akta tersebut.

Tanggung jawab notaris pada prinsipnya dapat dibebankan berdasarkan tanggung jawab kesalahan (based on fault of liability) dalam pembuatan akta perjanjian bank, pembebanan tanggung jawab kepada notaris merupakan suatu keharusan jika pelanggaran tersebut dilakukan secara sengaja sebagai bagian dari kelalaian notaris, akan tetapi jika kesalahan terletak pada subtansi isi akta maka notaris tidak dapat dimintakan pertanggungjawaban karena hanya bertugas mencatat apa yang dikehendaki oleh kontraktan dalam hubungan kontraktual.

Pada praktiknya kerugian yang diderita sangat jarang terjadi, karena para pihak melaksanakan hak dan kewajibannya sampai pada pelunasan, namun karena jarang terjadi inilah praktik penandatangan akta perjanjian tanpa kehadiran para saksi kerap dilakukan oleh para pihak sebagai praktik yang tidak mengandung risiko. Teori tanggung jawab Hans Kelsen menjelaskan kewajiban dilahirkan karena adanya hukum yang mengatur dan membebankan kewajiban kepada subyek hukum. Subyek hukum yang diberikan pembebanan kewajiban harus dapat melaksanakan kewajiban tersebut sebagai bentuk tanggung jawab dan ketaatan kepada perintah hukum. Melalaikan kewajiban tersebut menimbulkan adanya sanksi.

Notaris dapat dituntut oleh pihak yang dirugikan dan meminta kepada pengadilan untuk mengembalikan kerugian yang di derita terhadap akta yang dibuatnya jika dapat menjelaskan, membuktikan dan meyakinkan hakim, bahwa kerugian yang di derita dari akta tersebut karena kelalaian notaris dan ini merupakan suatu hal yang tidak mudah untuk membuktikannya. Pertanggungjawaban notaris dapat dimintakan baik secara keperdataan ataupun secara pidana, tanggung jawab secara perdata jika hal yang dilakukan notaris hanya mencakup pada wilayah kerugian keperdataan seperti pelanggaran karena ketidakhadiran para saksi, namun jika kelalaian tersebut 
dalam bentuk pemalsuan dokumen yang dilakukan notaris maka pertanggungjawaban secara pidana dapan dibebankan kepada notaris.

Pada hakikatnya notaris tidak bertanggung jawab kepada isi akta yang dibuatnya, karena isi akta merupakan kehendak para pihak. Notaris bersifat pasif hanya menuangkan hubungan kontraktual yang dikehendaki kontraktan. Menurut pendapat penulis, notaris juga mempunyai tanggung jawab terhadap isi akta karena jika isi akta suatu hal yang bertentangan dan berpotensi mengakibatkan kerugian kepada para pihak atau pihak lainnya. Misalnya dalam hal notaris membuat perjanjian akta otentik antara para pihak dalam hal pengalihan rumah tanpa persetujuan bank padahal obyek perjanjian merupakan dalam kuasa bank, hal yang demikian itu dapat dikatakan sebagai penyelundupan hukum dan notaris dapat dimintakan pertanggungjawaban oleh bank atau pihak lain yang dirugikan. Notaris jangan berpikir pada lepasnya tangung jawab dan mengesampingkan isi akta para penghadap tanpa mempertimbangkan risiko kerugian yang mungkin terjadi dikemudian hari. Notaris yang berkualitas tentu tidak akan melakukan praktik yang bertentangan tersebut meskipun secara teoritis notaris tidak bertanggung jawab atas isi akta yang dikehendaki oleh para pihak.

Pada tatanan praktisnya notaris dapat dimintakan nasihat hukum oleh penghadapnya terhadap kebenaran materil suatu akta, pada posisi ini notaris mempunyai independensi untuk memberikan nasihat yang benar dan dapat dipertanggungjawabkan. Akan tetapi, seringkali penyimpangan terhadap norma dilakukan oleh notaris karena memfasilitasi kepentingan klien. Praktik seperti ini jika dikemudian hari terjadi kerugian dari akta yang dibuat oleh notaris, maka notaris menurut hemat penulis dapat dimintakan pertanggungjawaban atas akta yang dibuatnya.

Kategori selanjutnya pengikatan akta perjanjian jual beli dengan tidak menghadirkan para saksi merupakan pelanggaran sehingga mengakibatkan kerugian kepada kontraktan dapat dikategorisasikan perbuatan melanggar hukum sebagaimana yang tercantum dalam Pasal 1365 KUH Perdata yang menyatakan, “tiap perbuatan melanggar hukum yang membawa kerugian kepada orang lain, mewajibkan orang yang karena salahnya menerbitkan kerugian itu, menggantikan kerugian tersebut." Makna dalam pasal tersebut terkandung unsur-unsur yang harus terpenuhi dari perbuatan melanggar hukum notaris tersebut diantaranya yatitu : pertama, adanya perbuatan melanggar hukum; kedua, harus ada kesalahan; ketiga, harus ada kerugian yang ditimbulkan; keempat, adanya hubungan kausal antara perbuatan dan kerugian.

Jika kita telaah berdasarkan unsur-unsur tersebut maka pengikatan akta pengikatan akta perjanjian jual beli yang tidak dihadiri para saksi yaitu 
jika adanya gugatan yang secara normatif adanya unsur perbuatan melanggar hukum, adanya kesalahan dan adanya hubungan kausal antara perbuatan dan kerugian yang dapat dibuktikan tanpa harus melakukan interpretasi lebih dalam, sehingga pada akhirnya yang menjadi kunci adalah apakah akta pengikatan akta perjanjian jual beli tersebut memiliki dampak kerugian kepada penghadap manakala terjadi pelanggaran. Hakim akan memutuskan berdasarkan fakta-fakta yang digali dalam proses pembuktian, sehingga dimungkinkan pembebanan pertanggungjawaban kepada notaris dalam bentuk penggantian kerugian dapat dilakukan dengan adil.

Teori tanggung jawab Hans Kelsen sejalan dengan Pasal $1365 \mathrm{KUH}$ Perdata bahwa perbuatan melanggar hukum yang mengakibatkan kerugian harus diberikan sanksi sebagai bentuk tanggung jawab dari perbuatan yang dilakukan oleh subyek hukum. Teori tanggung jawab Hans Kelsen juga sejalan dengan apa yang tersirat dalam Undang-undang Nomor 2 tahun 2014 Atas Perubahan Undang-Undang Nomor 30 tahun 2004 tentang Jabatan Notaris pada Pasal 40 yang menekankan pada tidak terpenuhinya kehadiran saksi sehingga mengakibatkan kerugian terjadi karena pelanggaran maka penuntutan tanggung jawab kepada notaris untuk menggantikan kerugian biaya dan bunga dapat dilakukan.

Pada beberapa kasus tertentu bahkan mengarah pada pidana, hal tersebut dikemukakan oleh Enriko Silalahi dan Akhmad Khisni ${ }^{13}$ dalam kesimpulannya menyatakan :

"Notary profession law (UUJN) does not mention the application of criminal sanctions but a legal action against violations committed by the Notary invites elements of forgery on intentional/negligence in making authentic letters/deeds. The deed contents are false. After being subjected to administrative sanctions/Professional code of ethics for the position of Notary and civil sanctions, the sanction can then be withdrawn and qualified as a criminal act committed by a Notary".

Di dalam pembuktian adanya unsur kesalahan terhadap notaris dapat dibuktikan dengan beberapa unsur diantaranya yaitu, pertama, hari, tanggal, bulan dan tahun menghadap, kedua, waktu dan tempat menghadap, ketiga, tandatangan yang terdapat dalam akta perjanjian. Untuk membuktikan kesalahan tersebut dibutuhkan kejujuran dari para pihak dan notaris ketika penandatanganan dilakukan. Jika di dalam penandatangan kehadiran saksi tidak ada namun dikemudian hari saksi itu tandatangan dalam waktu berbeda secara normatif dapat kita kategorisasikan hal tersebut mengandung unsur

${ }^{13}$ Enriko Silalahi at.all, Legal Review of Mallpractice Notary in The Notary's Deed, Jurnal Akta, Volumen 5, Issue 3, September, Universitas Islam Sultan Agung, 2018, hlm. 653. 
kesalahan yang dapat dimintakan pertanggungjawaban kepada notaris. Kesulitan dalam membuktikan unsur adanya kerugian dan kausalitas dari akta tersebut akan menjadi hal yang menentukan pembebanan tanggung jawab kerugian kepada notaris.

Secara normatif kerugian dalam perbuatan melanggar hukum ketidakhadiran para saksi dalam akta pengikatan akta perjanjian jual beli dapat dimintakan kerugian materil dan kerugian immateril, kerugian materil harus dapat dibuktikan dengan pasti dan tidak dapat ditaksasi dengan perkiraan, sedangkan kerugian immateril dalam bentuk kerugian tercemarnya nama baik dari akta yang dibuat atau dalam bentuk lainnya yang lazimnya kerugian immateril dikonversi menjadi kerugian materil dengan ukuran yang ditentukan oleh penggugat. Dengan demikian, unsur kesalahan notaris dan akibat dari akta pengikatan akta perjanjian jual beli tersebut harus dapat dibuktikan dengan pasti sehingga pembebanan tanggung jawab notaris dapat diputuskan dengan seadil-adilnya. Notaris di dalam menjalankan tugas dan fungsinya sebagai pejabat pembuat akta otentik juga dilindungi oleh undangundang, beberapa notaris dilibatkan dalam pembuatan akta yang mengandung unsur penipuan atau notaris diduga telah melakukan pembuatan akta otentik palsu serta beberapa penghadap menyangkal akta otentik yang telah dibuat notaris tersebut. Hal ini menjadi problematika jika tanggung jawab tersebut menjadi beban notaris, sehingga seyogyanya perlindungan hukum terhadap notaris merupakan hal yang tidak dapat dikesampingkan.

Perlindungan hukum terhadap notaris tidak berarti menghilangkan tanggung jawab notaris sebagai sanksi kesalahan yang dilakukannya, namun dimungkinkan jika notaris melakukan hal tersebut berada dalam ketidakhatihatian dan konsekuensi dari perbuatan tersebut adalah pembebanan tanggung jawab secara perdata dalam bentuk penggantian kerugian. Maka pembebanan tanggung jawab tersebut haruslah adil (fair), dimana dimungkinkan dalam pembuatan akta pengikatan akta perjanjian jual beli ketidakhadiran para saksi tersebut merupakan kehendak penghadapnya. Jika itu terjadi maka kesalahan dalam pembuatan akta perjanjian tersebut tidak dapat serta merta beban tanggung jawab yang ditanggung oleh notaris.

Notaris bertanggung jawab untuk melaksanakan perintah undangundang di dalam pembuatan akta perjanjian jual beli, sehubungan dengan kewenangannya tersebut sehingga notaris dapat dibebani tanggung jawab atas pembuatan akta otentik. Menurut pendapat penulis, teori tanggung jawab Hans Kelsen yang relevan dengan kewenangan notaris di dalam pembuatan akta otentik dapat dijabarkan sebagai berikut, pertama, tanggung jawab materil akta yang telah dibuat oleh notaris, tanggung jawab ini meliputi kebolehan notaris untuk melakukan penuangan akta yang dikehendaki oleh 
para kontraktan dalam hubungan kontraktual, dimana notaris harus memastikan isi akta tidak bertentangan dengan peraturan perundangundangan; kedua, tanggung jawab sebagai Pejabat umum (openbaar ambtenaar) yang berwenang membuat akta otentik, notaris harus menjunjung tinggi profesi notaris dengan mengedepankan kepastian hukum di dalam menjalankan tugas dan fungsinya dalam hal ini notaris memastikan akta-akta yang dibuatnya harus berdasarkan ketentuan peraturan perundang-undangan; ketiga, tanggung jawab perdata, notaris dapat dibebani penggantian kerugian jika akta yang telah dibuatnya menimbulkan kerugian; keempat, tanggung jawab pidana, notaris dapat dimintakan pertanggungjawabannya dihadapan pengadilan terhadap akta yang dibuatnya baik secara langsung atau tidak langsung turut serta dalam pemalsuan dokumen misalnya atau bentuk lain yang dapat diancam pidana; kelima, tanggung jawab administratif, notaris dapat dimintakan tanggungjawabnya secara administratif atas akta yang telah dibuatnya dan dapat dibebani hukuman administratif dalam bentuk peringatan tertulis, pemberhentian sementara, pemberhentian dengan hormat dan pemberhentian dengan tidak terhormat.

Bentuk tanggung jawab notaris adalah konsekuensi dari kewenangan yang diberikan oleh undang-undang kepada pejabat umum (openbaar ambtenaar) dalam upaya pencapaian kepastian hukum, tertib hukum dan keteraturan hukum. Menurut pendapat penulis tanggung jawab yang paling utama sebagai pejabat umum (openbaar ambtenaar) adalah tanggung jawab moral dengan memastikan pelaksanaan peraturan perundang-undangan dan kode etik notaris. Tanggung jawab tersebut dimaksudkan untuk memperbaiki kelalaian yang telah dilakukan oleh notaris dari akta otentik yang telah dibuatnya sehingga kepercayaan masyarakat terhadap pejabat umum dapat menciptakan tertib hukum.

Dari beberapa kasus yang penulis temukan mengenai akta pengikatan akta perjanjian jual beli yang tidak dihadiri para saksi dihadapan notaris karena beberapa hal diantaranya yaitu, pertama, notaris mengesampingkan kehadiran para saksi karena hal teknis waktu dan tempat perjanjian dilakukan, kedua, notaris mengikuti keinginan klien karena untuk melakukan penandatanganan dengan waktu dan tempat yang telah ditentukan klien, ketiga, kepentingan klien didahulukan untuk dilakukan penandatanganan karena kebutuhan dana pencairan, keempat, pengalaman notaris menunjukan penandatangan tanpa kehadiran saksi tidak menjadi masalah dikemudian hari karena debitur tidak sampai wanprestasi, kelima, lemahnya penegakan hukum kode etik notaris oleh Majelis Pengawas Daerah atau Majelis Kehormatan Notaris. 
Tanggung jawab notaris terhadap pengikatan akta perjanjian jual beli yang tidak dihadiri para saksi yang relevan dengan teori tanggung jawab Hans Kelsen dapat dipertanggungjawabkan dalam bentuk tanggung jawab perdata yang dimungkinkan notaris untuk dimintakan penggantian kerugian atau pertangungjawaban administatif dalam bentuk peringatan tertulis, pemberhentian sementara, pemberhentian dengan hormat dan pemberhentian dengan tidak terhormat, manakala dalam praktiknya mengakibatkan kerugian bagi para pihak.

Upaya-upaya yang harus dilakukan oleh notaris untuk memitigasi risiko terjadinya akta pengikatan akta perjanjian jual beli yang tidak dihadiri para saksi dapat dilakukan dengan berbagai metode diantaranya yaitu, pertama, memastikan notaris memberikan pemahaman kepada para penghadap terkait mekanisme pengikatan yang sesuai dengan peraturan perundang-undangan, pada titik ini notaris memberikan pencerahan kepada penghadap sehingga tertutup kemungkinan para penghadap meminta yang tidak sesuai dengan prosedur; kedua, notaris harus terbiasa tertib hukum dan tertib pencatatan sehingga di dalam pembuatan akta otentik notaris selalu mengedepankan prinsip kehati-hatian; ketiga, notaris berupaya untuk menjalankan tata kelola kantor notaris yang baik dan profesional dengan menjunjung tinggi nilai-nilai kode etik notaris dan peraturan perundang-undangan, sehingga pelayanan terhadap klien tidak mereduksi nilai-nilai etik sebagai notaris.

\section{Penutup}

Simpulan

Pengikatan akta perjanjian jual beli di hadapan notaris tanpa dihadiri para saksi memberikan kepastian hukum kepada para kontraktan karena bersifat otentik berdasarkan pasal 1868 KUHPerdata dan telah memenuhi syarat formil dan materil, otensitas akta tidak berubah meskipun pada proses pengikatannya dilakukan tanpa dihadiri para saksi. Kedua, Notaris bertanggung jawab secara penuh terhadap akta yang dibuatnya bilamana ada syarat formil dan materil yang tidak dapat dipenuhi secara lengkap, dan dalam tatanan praktisnya pengikatan akta perjanjian jual beli tersebut mengakibatkan kerugian terhadap para pihak, maka notaris dapat dituntut secara keperdataan dan wajib mengganti kerugian yang ditimbulkan.

\section{Saran}

Notaris harus menjalankan tugas dan fungsinya dengan baik berdasarkan peraturan perundang-undangan serta menjunjung tinggi kode etik notaris. Para saksi harus dihadirkan untuk menghadap kepada notaris dan melakukan penadatanganan pada waktu yang bersamaan. Penghadap harus mentaati 
mekanisme pengikatan akta perjanjian jual beli yang harus dilakukan berdasarkan ketentuan peraturan perundang-undangan. Pemerintah harus membuat regulasi untuk memberikan peningkatan kualitas notaris dalam bentuk pendidikan etika moral secara khusus dan terus menerus.

\section{Daftar Pustaka}

\section{Buku}

Agus Yudha Hernoko, Hukum Perjanjian Asas Proposional Dalam Kontrak Komersial, Kencana, Jakarta, 2014.

Anton Suyatno, Kepastian Hukum Dalam Penyelesaian Macet Melalui Eksekusi Jaminan Hak Tanggungan Tanpa Proses Gugatan Pengadilan, Kencana, 2016.

E. Fernando M. Manulang, Legisme Legalitas Dan Kepastian Hukum, Frenada Media Group, Jakarta, 2016.

Habib Adjie, Hukum Notaris Indonesia-Tafsir Tematik Terhadap UndangUndang Nomor 30 Tahun 2004 tentang Jabatan Notaris, Rafika Aditama, Bandung, 2008.

I Ketut Oka Setiawan, “Hukum Perikatan”, Sinar Grafika, Jakarta, 2016.

Pengurus Pusat Ikatan Notaris Indonesia, Jati Diri Notaris Indonesia, PT. Gramedia Pustaka, Jakarta, 2009.

R. Soegondo Notodisoeryo, Hukum Notaris Di Indonesia Suatu Penjelasan, PT. Raja Grafindo Persada, Jakarta, 1993.

\section{Jurnal}

Bernhard Limbong, Opini Kebijakan Agraria, PT. Dharma Karsa utama, Jakarta, 2014.

Enriko Silalahi at.all, Legal Review of Mallpractice Notary in The Notary's Deed, Jurnal Akta, Volumen 5, Issue 3, September, Universitas Islam Sultan Agung, 2018.

Efty Hendaru Sudibyo at.all, Peranan Notaris Dalam Pembuatan Akta Izin Roya Hak Tanggungan Karena Hapusnya Hutang Dalam Perspektif Kepastian Hukum, Magister Kenotariatan, Universitas Islam Sultan Agung, Jurnal Akta, Volume 4 Nomor 2 Juni 2017.

Mariah kamelia at.all, Peran Notaris Dalam Pembuatan Akta Perjanjian Kredit Dalam Perspektif Hukum Positif dan Hukum Islam, Program Magister Kenotariatan, Universitas Sultan Agung, Jurnal Fakta, Volume 4 Nomor 4, Desember, 2017.

Felix The, Perlindungan Hukum Atas Kriminalisasi Terhadap Notaris, Fakultas Hukum, Universitas Diponegoro, Jurnal Masalah-Masalah Hukum, Jilid 46, 3 Juli 2017. 